\title{
COURTS AND CORPORATIONS: A COMMENT ON COFFEE
}

\author{
Jonathan R. Macey*
}

In his essay on the role of the judiciary in corporate law, Professor John C. Coffee, Jr. contends that the differences between the competing sides in the mandatory/enabling debate ${ }^{1}$ in corporate governance have been greatly overstated because both sides have ignored the important role of a central institutional actor, namely the judiciary. According to Professor Coffee, courts, using well-recognized techniques to interpret statutes and intrafirm contracts, often will reconcile whatever tension may exist between contractarians and anticontractarians. Anticontractarians, according to Coffee, generally misperceive the nature of corporate law because they fail to understand the extent to which courts adjust the mandatory statutory provisions imposed by legislatures. Contractarians, on the other hand, misperceive the nature of corporate law because they fail to appreciate the role that courts play in evaluating the contractual innovations suggested by the parties against the backdrop of the fiduciary duties of care and loyalty owed by directors and managers to their shareholders.

I fully agree with Professor Coffee's basic premise, which is that the central role played by courts must be understood before the concept of

* Professor of Law, Cornell University.

1. As used in Professor Coffee's article, The Mandatory/Enabling Balance in Corporate Law: An Essay on the Judicial Role, 89 Colum. L. Rev. 1618 (1989), as well as in this Comment, the phrase "mandatory/enabling debate" refers to the debate between those who argue that the structure of American corporate law consists (or ought to consist) of a series of mandatory rules, and those who argue that American corporate law consists (or ought to consist) primarily of a series of default rules that serve as a standard form contract that the parties can modify easily by substituting their own contractual provisions. Professors Melvin Eisenberg and Victor Brudney are principal exponents of the view that mandatory rules comprise the essential elements of corporate law, see, e.g., M. Eisenberg, The Structure of the Corporation: A Legal Analysis 134-211 (1976); Brudney, Corporate Governance, Agency Costs, and the Rhetoric of Contract, 85 Colum. L. Rev. 1403 (1985), while Judge Frank H. Easterbrook and Professor Daniel R. Fischel are principal exponents of the view that corporate law rules ought to be enabling.

While they clearly take a more laissez faire attitude than Eisenberg and Brudney, even Easterbrook and Fischel often have taken the position that corporate law rules ought to be mandatory. See, e.g., Easterbrook \& Fischel, The Proper Role of a Target's Management in Responding to a Tender Offer, 94 Harv. L. Rev. 1161, 1175, 1189, 1201 (1981) (arguing that firms ought not to be permitted to allow management to resist hostile tender offers because of economic waste and free-rider problems); Easterbrook \& Fischel, Mandatory Disclosure and the Protection of Investors, $70 \mathrm{Va}$. L. Rev. 669, 697-99 (1984) (arguing that the incentives of the private market are insufficient to cause private firms to disclose to investors the optimal amount of information about themselves). In fact, there are no corporate law scholars who take the view that corporate law rules should be strictly enabling. 
corporate governance can be evaluated or even categorized. On the other hand, an adjustment must be made to Coffee's argument in order to achieve the reconciliation he is attempting. When courts adjust the mandatory rules imposed by legislatures, they employ a hypothetical bargaining approach that first determines what arrangement the parties themselves would have adopted ex ante and then requires that subsequent transactions conform to that hypothetical bargain. It is only in this way that mandatory rules can properly be labelled "contractarian." I find the implication of Professor Coffee's analysis quite profound. It indicates that the only respectable academic approaches to corporate law are those that accord judges the central, decisive role in American corporate life. This is an implication well worth exploring.

\section{The Role of the Courts}

Professor Coffee invokes numerous examples from existing case law to show that courts have a wide range of alternatives at their disposal when interpreting statutes that appear to be mandatory. ${ }^{2}$ The implication of his analysis is that courts play a central role in corporate governance even when they appear to be merely interpreting statutes.

While Professor Coffee clearly is correct that the necessity of interpreting the statutes that govern the behavior of corporations forces the legislatures that enact such statutes to share power with courts, it is not at all obvious how this judicial power unites the competing views of the contractarians and the anticontractarians. At first blush, the process that Professor Coffee describes appears merely to substitute the mandatory rules imposed by one institution (the legislature) with the mandatory rules imposed by another, even less malleable institution (the judiciary). After all, as Coffee recognizes, courts as well as legislatures are capable of generating mandatory rules. ${ }^{3}$ Consequently, the interpretive role played by courts may simply substitute one form of mandatory rule for another and therefore have little, if anything, to do with the mandatory/enabling debate. This last point seems particularly true in light of the fact that there appears to be no reason to assume that those who favor mandatory corporate law rules prefer that these mandatory rules emanate from legislatures rather than courts. ${ }^{4}$ After all, as Coffee recognizes, ${ }^{5}$ those who favor mandatory rules are con-

2. See, e.g., Coffee, supra note 1 , at 1628-36, 1644-47.

3. Indeed, Part IV of Coffee's article is devoted to the consideration of "when, if ever, courts should make new mandatory rules." See id. at 1628.

4. In light of the responsiveness of legislatures to lobbying by corporate management and the corporate bar, there may be good reason to prefer the corporate law rules generated by judges over the rules generated by legislatures since judges generally are somewhat more insulated from political pressures than are legislators. Cf. Romano, Answering the Wrong Question: The Tenuous Case for Mandatory Corporate Laws, 89 Colum. L. Rev. 1599, 1605 (1989) (legislative enactment often prompted by corporate bar rather than shareholder interest).

5. See Coffee, supra note 1 , at 1658 . 
cerned about the substance of such rules and have not focused on the process by which those rules are generated. They are interested in outcomes. $^{6}$ Accordingly, those who favor mandatory rules will prefer the rules that reach the results they deem best, with little regard for whether the rules emanate from the legislature or from the courts.

The point of all of this is not to say that Professor Coffee is wrong, but to emphasize that his arguments are rather more subtle than they may appear to be at first. Only by applying a contractarian perspective to all corporate law rules-including mandatory rules-do courts reconcile the tension between the enabling and the mandatory elements of corporate law. By evaluating corporate conduct against an existing background of legal norms, such as the fiduciary duties of care and loyalty, the mandatory rules that courts enforce constitute a sort of "metacontract" that is consistent with both the contractarian perspective of an Easterbrook or a Fischel and the anticontractarian perspective of an Eisenberg or a Brudney.

This meta-contract perspective is commonly known as the hypothetical bargaining approach, and it requires courts to interpret vague terms (whether in intrafirm charter provisions or in statutes) as being identical to the provisions that the parties to the dispute would have meant those terms to be if they were discussing the terms ex ante. ${ }^{7}$ However, Professor Coffee purports to reject the hypothetical bargaining approach as being inconsistent with the traditional legal approach under which corporate officers and directors are said to owe fiduciary duties to shareholders that require them to exercise their powers only to benefit the shareholders. ${ }^{8}$

Professor Coffee's rejection of the hypothetical bargaining approach is odd for two reasons. First, as noted above, the hypothetical bargaining approach appears to be necessary in order to harmonize the views of those who favor mandatory rules and those who favor enabling rules. If courts are not engaged in a hypothetical bargaining approach, all they are doing when applying traditional fiduciary duty analysis is enforcing an alternative series of mandatory rules. Enforcement of such mandatory rules by courts is not only impossible to reconcile with the contractarian perspective, but difficult to condone on legitimacy grounds, since courts should not substitute their own judgment for that of the legislature absent a clear constitutional predicate for so doing.

Professor Coffee's rejection of the hypothetical bargaining approach is also odd because it is not clear that there is a difference between

6. See M. Eisenberg, supra note 1 (the core of corporate law, including fiduciary duties, consists of mandatory rules which can only be defended on the basis of the substantive outcomes they generate).

7. In the case of a charter amendment, ex ante denotes the time the charter provision was adopted. In the case of a statute, ex ante denotes the time shares were sold to the public.

8. Coffee, supra note 1 , at $1679-80$. 
the hypothetical bargaining approach and its purported rival, the traditional approach. The better argument seems to be that the approaches are tbe same. The hypothetical bargaining approach is simply a more formal restatement of traditional fiduciary duty analysis. Both approaches require judges to evaluate corporate actions in order to determine whether the actions enhance shareholder welfare.

Professor Coffee describes the hypothetical bargaining approach as a "rival" of the traditional approach, ${ }^{9}$ although he concedes that the approaches "will often produce the same result." 10 Indeed, it is impossible to imagine a situation in which the results would be different. Both approaches instruct courts to view corporate transactions from the shareholders' perspective. Indeed, the hypothetical bargaining approach can be viewed as a more precise formulation of the fiduciary duty approach because it seeks to provide some measure of guidance to courts about how to think about shareholder welfare and is explicit about the fact that the shareholders' perspective ought to dominate judicial evaluation of corporate conduct.

Professor Coffee's real objection to the hypothetical bargaining approach appears to be that it is more indeterminate than fiduciary analysis because it "invites the court to engage in an extraordinary range of judicial speculations about what maximizes shareholder value."11 I agree with Coffee's general observation that the hypothetical bargaining approach often yields results that appear indeterminate. But this indeterminacy does not distinguish the hypothetical bargaining approach from the fiduciary duty approach, because the latter is equally indeterminate. ${ }^{12}$ Part II of this Comment uses Coffee's observations to show why this inevitably will be the case, and argues that this indeterminacy is a source of strength rather than of weakness.

\section{Id. at 1679 .}

I0. Id.

11. Id.

12. Professor Coffee claims that the traditional fiduciary duty analysis is more clear than the hypothetical bargaining approach because "the normal default rules of fiduciary duty would generally govern unless the parties have clearly opted out by a valid charter provision." Id. at 1679-80. But the hypothetical bargainers would wholeheartedly agree that parties should not be allowed to cast off their fiduciary duties so easily. Rather, the hypothetical bargainers would say that the fiduciary duties of officers and directors require them to maximize aggregate shareholder wealth. See, e.g., Easterbrook \& Fischel, Corporate Control Transactions, 91 Yale L.J. 698, 702-03 (1982). And, like Coffee, the hypothetical bargainers would not permit officers and directors to avoid this fiduciary duty/hypothetical bargain without a clear expression from the parties that they intended to do so. The hypothetical bargainers might even agree with Professor Coffee that all of the burdens of proof, persuasion and production, should be against those arguing for opting out.

Indeed, the unity between Coffee's approach and that of the hypothetical bargainers is manifest in the very language Professor Coffee uses to describe the mandatory approach. He invokes standard contract rhetoric to describe an approach that is supposed to be noncontractarian in nature. For example, when Coffee describes the fiduciary standards as "the normal default rules of fiduciary duty" which will apply unless the 
Professor Coffee's false dichotomy between the perspective of the hypothetical bargainers and that of those who embrace the fiduciary duty approach leads him erroneously to conclude that contractarians fail to appreciate the role that courts play in evaluating the contractual innovations suggested by the parties to the corporate contract. Once it is seen that there is no distinction between the role envisioned for courts by those who embrace a contractarian perspective and those who embrace a fiduciary duty perspective, it becomes clear that courts have a major role to play in evaluating the terms of the implicit contracts that comprise the modern corporation.

\section{The Policymaker's Dilemma and the Futility of Nontransaction-Based Corporate LaW Rules}

Imbedded in Professor Coffee's article is the notion that courts rather than legislatures must assume the dominant role in corporate governance, but he does not explain why this is the case. The explanation is inextricably linked to the problem of indeterminacy identified above and is grounded in the phenomenon known as the "policymaker's dilemma." 13 If Coffee is correct that the differences between the advocates of mandatory rules and those of enabling rules are more apparent than real, the focus of the debate shifts to whether it is possible to develop generalized nontransaction-based corporate law rules that enhance shareholder welfare.

The point becomes clear when we look at Professor Coffee's observations about poison pills. In explaining the role played by courts in

parties have "clearly opted out," Coffee, supra note 1 , at 1679-80, it is hard to avoid the conclusion that it is about contracts (albeit hypothetical ones) that he is speaking.

Jordan v. Duff \& Phelps, Inc., 815 F.2d 429 (7th Cir. 1987), cert. dismissed, 108 S. Ct. 1067 (1988), is the sole case Professor Coffee uses to illustrate his argument that the hypothetical bargain approach is indeterminate. See Coffee, supra note 1 , at 1680-81. The issue in that case was whether a buy-sell agreement requiring an employee to sell his stock back to the corporation at book value "for any reason including resignation, discharge, death, disability or retirement" would force a corporation to disclose, inter alia, ongoing negotiations with a potential merger partner, or a decision by the firm's board of directors to "shop the firm" to potential bidders. Jordan, 815 F.2d at 432-33.

The hypothetical bargainers, Judges Frank Easterbrook and Richard Posner, disagreed about the correct result. Judge Easterbrook, writing for the majority, held that prior precedent required close corporations to disclose impending merger negotiations. Id. at 434 . He saw the case as turning on the applicability of SEC Rule $10 \mathrm{~b}-5$ to the merger of a closely held corporation. 1d. Judge Posner saw the case as turning on the proper interpretation of the plaintiff's employment contract. ld. at 445-52 (Posner, J., dissenting).

In other words, this case did not turn on an interpretation of the fiduciary duties owed to the plaintiff under general corporate law. Thus, the case does not support Coffee's argument that the hypothetical bargaining approach is more indeterminate than the fiduciary duty approach. It supports the proposition that the law of Rule 10b-5 is murky when securities transactions are consummated with employees.

13. Macey, Takeover Defense Tactics and Legal Scholarship: Market Forces Versus the Policymaker's Dilemma, 96 Yale L.J. 342, 351 (1986). 
construing implicit corporate contracts, Professor Coffee observes that the pill "provides a paradigm of a novel contractual provision that can arguably be used either to maximize shareholder wealth or to entrench existing management." 14 But to understand the central role of the courts in corporate governance, we first must recognize that this observation is not confined to poison pills. In fact, it applies to virtually every device, scheme or transaction available to corporate decision makers, from greenmail and poison pills, which do not appear benign, to staggered terms for boards members, dividend payments to shareholders and the issuance of new shares of stock, which do appear benign.

The dilemma is that policymakers cannot benefit shareholders by developing rules that successfully regnlate whole classes of corporate transactions. This has profound implications for our understanding of corporate governance. Unlike legislatures, courts can respond to the phenomenon on a case-by-case basis by upholding the validity of consensual provisions in certain cases but not in others. For example, as Coffee points out, ${ }^{15}$ in Petty $v$. Penntech Papers, Inc. ${ }^{16}$ a Delaware court held that a charter provision providing that a corporation could redeem the whole or any part of its Series A preferred stock was limited by Delaware's fiduciary rules that deny corporate management the right to use corporate funds to entrench themselves in office. ${ }^{17}$ This result was obtained despite the fact that redemption clearly was authorized under the laws of Delaware and the charter of the corporation. ${ }^{18}$

Similarly, in Katzowitz $v$. Sidler, ${ }^{19}$ the New York Court of Appeals refused to permit a group of directors to issue new stock because no business purpose existed for the issuance, and the issuance was done in such a way as to violate the fiduciary duty owed by directors to minority shareholders in a close corporation. ${ }^{20}$ The court reached this result despite the fact that issuing additional shares of stock was clearly permissible under applicable state law and that the minority shareholder was given the opportunity to retain his proportionate interest in the firm by exercising his preemptive right. ${ }^{21}$

These examples demonstrate that seemingly benign transactions can disadvantage shareholders just as transactions that apparently exploit shareholders can enhance their welfare. Because harm to shareholders results not from particular types of transactions, but rather from the circumstances in which the transactions are employed, rules

14. Coffee, supra note 1 , at 1653 .

15. Id. at 1641 .

16. 347 A.2d 140 (Del. Ch. 1975).

17. Id. at $142-43$.

18. Id. at 141 .

19. 24 N.Y.2d 512, 249 N.E.2d 359, 301 N.Y.S.2d 470 (1969).

20. Id. at 519-20, 249 N.E.2d at 364,301 N.Y.S.2d at $476-77$.

21. Id. at 516, 249 N.E.2d at 362, 301 N.Y.S.2d at 474 . 
that purport to govern classes of transactions are both underinclusive and overinclusive. Such rules are underinclusive because they inevitably validate corporate conduct that is detrimental to shareholder welfare. They are overinclusive to the extent that they are viewed as mandatory and thus prohibitive of transactions that would conflict with the rules yet increase shareholder wealth.

The policymaker's dilemma leads inevitably to the conclusion that even well-meaning legislatures often will be unable to generate wealthincreasing responses to problems in corporate governance. The correct response often will require case by case analysis because of the necessity for close attention to specific fact patterns. Needless to say, those who take the position that corporate law rules ought to be a series of mandatory rules with inflexible directives to corporations and to courts do not appreciate the policymaker's dilemma.

While Professor Coffee appears to recognize the policymaker's dilemma, at least as it relates to the poison pill, it is not clear how the standard he suggests for determining when courts should permit opting out of statutes or fiduciary duties represents an improvement over the hypothetical bargaining approach he claims to reject. First, his requirement that a provision should be upheld only if it does not "confict with the clear purpose of any statutory provision or with an established public policy intended to protect persons or interests other than shareholders" 22 is too vague to provide any guidance. Nor does it adequately take into account the public choice perspective, namely, that both public and private entities that generate legal rules often promulgate rules that transfer wealth rather than create it. ${ }^{23}$

Second, his requirement that a provision be either "sufficiently specific and limited in its application that the parties could appreciate its likely impact at the time they approved it," or amount "to a substitution of an adequate alternative procedure that the parties could reasonably believe would better serve their interests,"24 does not recognize that parties who wish to extricate themselves from the force of existing legal norms may not have a good alternative at the time of contracting. In such situations, the parties want to give courts flexibility to try a new solution in light of the fact that they view the existing procedure to be inadequate. Put another way, it is surprising that Professor Coffee advocates specific and limited rules. General and seemingly open-ended provisions may well be better than specific provisions because general provisions enable courts to provide remedies that fit particular circumstances. It seems incongruous for Coffee to celebrate the role of the courts and yet simultaneously prefer rules that constrain their ability to involve themselves in corporate governance.

22. Coffee, supra note 1 , at 1665 .

23. See Macey \& Miller, Toward an Interest-Group Theory of Delaware Corporate Law, 65 Tex. L. Rev. 469, 498-509 (1987).

24. Coffee, supra note 1 , at 1665 . 
The argument that there is not even a tiny bit of sunlight separating Professor Coffee's position from the hypothetical bargaining approach seems proven by Coffee's admonition that courts look at a provision adopted by charter amendment to determine whether the parties could have reasonably believed it would better serve their interests. ${ }^{25}$ This legal standard is nothing less than a precise restatement of the hypothetical bargaining approach.

Finally, Professor Coffee advocates that provisions adopted by charter amendment must be approved by a disinterested majority of the shareholders under circumstances in which rejection of the amendment would not cause them to be worse off than they were prior to the proposal of the amendment. ${ }^{26}$ This requirement is strange in light of the fact that some of the most nefarious examples of wealth-reducing transactions occur without a shareholder vote. 1 t is doubtful that shareholders would benefit from the canonization of a rule that would provide even greater incentive to accomplish changes through methods that do not require a shareholder vote. Again, the similarity between Coffee's decision rule and the hypothetical bargaining approach is apparent.

Thus, my basic problem with the analytical framework that Professor Coffee presents in Part 111 of his article is that it does not attempt to resolve the policymaker's dilemma, which makes generalized rules that displace transaction-specific inquiries wholly inappropriate in the corporate setting. ${ }^{27}$ Further, despite the wording of his proposed legal standard, 1 have serious doubts that Professor Coffee would object to an insufficiently specific legal rule that unambiguously increased shareholder wealth in a particular case by dramatically raising the price of the firm's shares. Thus, he has not succeeded in solving the policymaker's dilemma or in distancing himself in any meaningful way from those who embrace a hypothetical bargaining approach.

\section{The Judicial Role in lNTerpretation of Statutes and INTERNAL CORPORATE LAW RULES}

The judiciary's central role in corporate law arises from the existence of the policymaker's dilemma, which renders legislative enactments unhelpful in a wide variety of contexts. As Professor Coffee points out, an additional reason for support of a broad judicial role is that internal rules of corporate governance, as well as statutes that purport to govern corporations, can be privately motivated, and serve the

25. Id.

26. Id.

27. This is particularly odd in light of the fact that Professor Coffee himself appears to recognize the existence of the policymaker's dilemma, at least in certain contexts. For example, his discussion of poison pills makes it clear that these devices may be used "either to maximize shareholder wealth or to entrench existing management." Id. at 1653. The inability to make this distinction is the core of the policymaker's dilemma. 
narrow goals of special interests such as incumbent management. ${ }^{28}$ As Coffee suggests, the fiduciary duties of care and loyalty are intended to provide the judiciary with a mechanism for dealing with this problem. ${ }^{29}$ Courts can strike down transactions that fit the letter of the law by declaring them to be breaches of management's fiduciary duties. ${ }^{30}$

Having courts apply a public-regarding interpretation of corporate law rules provides an independent justification for an active judicial role in the realm of corporate governance. In this regard, Professor Coffee compares my work to Judge Easterbrook's and points out what he believes to be a tension ${ }^{31}$ between my view that corporate law ought to be exclusively contractual ${ }^{32}$ and my view that statutory construction should start with the premise that legislation should be construed by courts as though it is public regarding. ${ }^{33}$ But there is no such tension: just as courts can and should construe statutes so that they advance the public interest, so too should courts interpret intracorporate rules so that they further shareholder welfare. ${ }^{34}$ Legislation should be treated as though the enacting legislature were acting in a public-regarding fashion, and courts should employ an ex ante perspective to evaluate corporate transactions as though the corporation initially had agreed to act to maximize shareholder wealth absent clear evidence of a contrary intention on the part of all the relevant parties. ${ }^{35}$ An active judicial role

28. See id. at $1683-85$.

29. Id.

30. An additional justification for an active judicial role has been noted by Professor Roberta Romano. Romano, Law as a Product: Some Pieces of the Incorporation Puzzle, 1 J.L. Econ. \& Organization 225, 280 (1985). She observes that a major asset of the state of Delaware is the experience and expertise of its judiciary in the area of corporate law. Id. The existence of a group of judges with competence in matters of corporate governance contributes to Delaware's attractiveness as a situs of incorporation. Romano's point dovetails nicely with Coffee's. The greater the experience and expertise of the court, the greater the value of its ability to interact with legislatures and boards of directors in the ways Coffee describes.

31. Id. at 1684 .

32. See, e.g., Haddock, Macey \& McChesney, Property Rights in Assets and Resistance to Tender Offers, 73 Va. L. Rev. 701 (1987); Macey, From Fairness to Contract: The New Direction of the Rules Against Insider Trading, 13 Hofstra L. Rev. 9 (1984); Macey \& McChesney, A Theoretical Analysis of Corporate Greenmail, 95 Yale L.J. 13 (1985).

33. Macey, Promoting Public-Regarding Legislation Through Statutory Interpretation: An Interest Group Model, 86 Colum. L. Rev. 223 (1986).

34. In the corporate context, "public regarding" is synonymous with "shareholder regarding."

35. By this I do not mean to suggest that I am equally distrustful of the legislature in all contexts. Where there is a real measure of competition among jurisdictions, as in the case of corporate charters, there is a far greater likelihood that lawmakers will promulgate welfare-enhancing legal rules. See Macey \& Miller, supra note 23. But the presence of some degree of competition still does not ensure that public-regarding legislation will dominate. Cf. Macey, State Anti-Takeover Legislation and the National Economy, 1988 Wis. L. Rev. 467 (arguing that state antitakeover legislation is welfare reducing both for corporate shareholders and for the economy in general). 
in the interpretation of corporate law rules, following the path that 1 have proposed for courts to follow with regard to statutes generally, is thus desirable. ${ }^{36}$

\section{CONCLUSION}

\section{In sum, I agree fully with Professor Coffee that the judiciary has an}

36. Before one wholeheartedly embraces an active judicial role in corporate governance, one should observe that all of the analysis thus far (both from Coffee and from me) has focused exclusively on the benefits to shareholders and society of encouraging an active judicial role in corporate governance. The analysis ignores the costs associated with the intense judicial involvement in corporate life implied by both the hypothetical bargainers and those who favor mandatory rules. But see Fischel \& Bradley, The Role of Liability Rules and the Derivative Suit in Corporate Law: A Theoretical and Empirical Analysis, 71 Cornell L. Rev. 261 (1986) (arguing that derivative law suits, the principal means by which courts enforce legal rules that protect shareholders against directors' misfeasance, may not advance shareholder welfare).

Unfortunately, many of the costs associated with a litigation-centered corporate governance system are difficult to quantify. For example, officers and directors who fear litigation will refrain from engaging in certain wealth-maximizing transactions because most of the benefits of such transactions will inure to the shareholders, while the costs of any errors in the decision-making process will be disproportionately borne by the directors and officers who must defend their decisions in court. In addition to making managers more risk averse, the current system also changes the decision-making process within the firm. Instead of focusing exclusively on shareholder wealth maximization, corporate planning is now done with an eye on future litigation. See Macey \& Miller, Trans Union Reconsidered, 98 Yale L.J. 127, 134-35 (1989). In addition, judicial and legislative tinkering impedes the ability of market forces to constrain managerial misbehavior, and, in the final analysis, merely substitutes the decisions of one set of agents (the courts) for another (the corporation's board of directors). Dooley \& Veasey, The Role of the Board in Derivative Litigation: Delaware Law and the Current ALI Proposals Compared, 44 Bus. Law. 503, 519-22 (1989). Finally, the chronic divergence of interests between plaintiff-shareholders, who are generally motivated by the prospect of attorneys' fees, and nonplaintiff-shareholders, who bear the costs of the litigation but enjoy only a fraction of the benefits, greatly exacerbates the problems of America's litigation-oriented corporate governance system.

Judges are now at the center of the American system of corporate governance. Whether we describe their activities as enforcing mandatory fiduciary duties or as construing hypothetical ex ante bargains is really a minor point in the context of this larger reality. The important question is whether the benefits of this peculiarly American system outweigh the costs. Coffee's article is a powerful illustration of the fact that there is virtually no debate on this question from one quarter: all the lawyers agree that a litigation-intensive system is desirable. In light of the seemingly insatiable demand that the current system creates for the services of corporate lawyers, one wonders whether we lawyers really are the most qualified to address this question. And, the desirability of a judicio-centric system of corporate governance becomes even more questionable when one looks to countries, such as Japan, where judicial intervention into matters of internal corporate governance is virtually unheard of, see generally Ramseyer, The Costs of the Consensual Myth: Antitrnst Enforcement and Institutional Barriers to Litigation in Japan, 94 Yale L.J. 604, 604 (1985) ("there are indeed few lawyers and lawsuits in Japan"); Lieberman, Confucius's Lesson to Litigants, N.Y. Times, July 9, 1984, at 19, col. 1 (describing mediation as dominant method of dispute resolution); Land Without Lawyers, Time, Aug. 1, 1983, at 64 (describing limited role of Japanese lawyers). 
important, albeit frequently misunderstood, role to play in corporate governance. As Professor Coffee points out, this role has a dramatic effect on both the contractarian and the anticontractarian visions of corporate law. My view, however, is that the judiciary's role serves to validate the hypothetical bargaining approach of the contractarians because an active judiciary of disinterested experts in corporate law, such as the Delaware Supreme Court, fills in missing terms from standardized corporate contracts by interpreting those contracts so as to maximize shareholder wealth. Indeed, it seems to me that recognition of the validity of the hypothetical bargaining approach is an essential, though unrecognized, condition for acceptance of Professor Coffee's own arguments. 